\title{
CARBON COMPOUNDS: Pollution Aspects
}

Khadka Yagyarath

\begin{abstract}
Carbon is one of the major elements by which organic compounds cannot be imagined. Its compounds are very useful in human life as well as for nature. For example, carbon dioxide is used during photosynthesis in plants and CFCs is used in manufacturing of aerosol sprays and as refrigerants. In contrast, serious harmful effects are seen with over exposure or with increasing in level of its compounds. Use of carbon compounds awareness is necessary for its use in different purposes. Carbon monoxide and carbon dioxide released by the complete combustion of fossils and by automobile exhaust causes carbon pollution along with other various causes. Reuse and recycling of carbon compounds minimizes its pollution. Carboxyhemoglobin formed by combination of carbon monoxide with red blood cell is also more fatal. As we know, different gases formed due to the combination of carbon with other elements causes various changes like climate change, destruction of heritage goods (acid rain), different human risk, flooding etc. So, pollution of carbon should be managed before it causes any huge harmful effects. Finally, carbon related pollution leads to global warming, greenhouse effects, ozone layer depletion, ocean acidification, acid rain, climate change and also fatal to human beings.
\end{abstract}

Keywords: allotrope, radiation, precipitation, acidification, depletion, emission, photosynthesis, carbon capping, pollution.

\section{Introduction}

Carbon is a nonmetallic chemical element that readily forms compounds with many other elements and is a constituent of organic compounds in all known living tissues. It is the most abundant element in earth's crust and second most abundant element in human body by mass after oxygen. Carbon has two main forms (allotropes): diamond and graphite (allotropes- each of two or more different physical forms in which an element can exist, both the chemical and physical properties of allotropes display marked differences for a given element). It has atomic weight of 12.011, atomic number of 6 and specific gravity of 3.51 at $20^{\circ} \mathrm{C}$ of diamond and 2.26 at $20^{\circ} \mathrm{C}$ of graphite.

Pollution is defined as the addition of any harmful substance i.e. solid, liquid or gas, or any form of energy such as sound, heat or radioactivity to the environment at a rate faster than it can be dispersed, diluted, decomposed or recycled. Pollution damages the quality of air, water, land and also adversely affects human life. There are various sources of pollutants like car spew pollutants from their exhaust pipes, burning coals, large livestock farms, chemical plants, oil refineries, PVC factories, plastic factories, metal production factories and other heavy industries. 


\section{Role of carbon in pollution}

\section{A. Carbondioxide}

Carbondioxide occurs naturally in the atmosphere and accounts for less than 1 percentage of atmospheric gases. It is also an essential ingredient in photosynthesis. As the level of carbondioxide rises, the effect in air pollution also rises simultaneously.

\section{Sources}

There are both natural and human sources of carbondioxide. Natural sources include decomposition, ocean release, volcanic eruption and cellular respiration. Human sources come from activities like deforestation, cement production and burning of fossil fuels like coal, oil and natural gas.

\section{Affects of carbondioxide in pollution}

\section{Greenhouse effect}

Greenhouse effect is the natural phenomenon which warms the earth's surface. Falling of sun rays in the earth atmosphere partly absorbed and partly reflected and reradiated by greenhouse gases. The absorbed energy of the sun is responsible for the warming of the earth as well as atmosphere.Normal level of carbon dioxide in the atmosphere helps the earth to maintain the temperature for the living beings. Higher level of carbon dioxide due to air pollution traps radiation at ground level, creating ground level ozone. This prevents the earth from cooling at night. Heat gets trapped inside the blanket of greenhouse gases and leads to global warming. Greenhouse gases like carbon dioxide, nitrous oxide, methane, etc. trap heat in the atmosphere. With high concentration, they lead to unnatural warming. The concentration of carbon dioxide in the atmosphere are naturally regulated by many processes, is the part of global carbon cycle. Presence of carbon between earth's surface, atmosphere and ocean is dominated by natural process: photosynthesis (process by which the green plants and certain organisms use sunlight to synthesize nutrients from carbon dioxide and water).

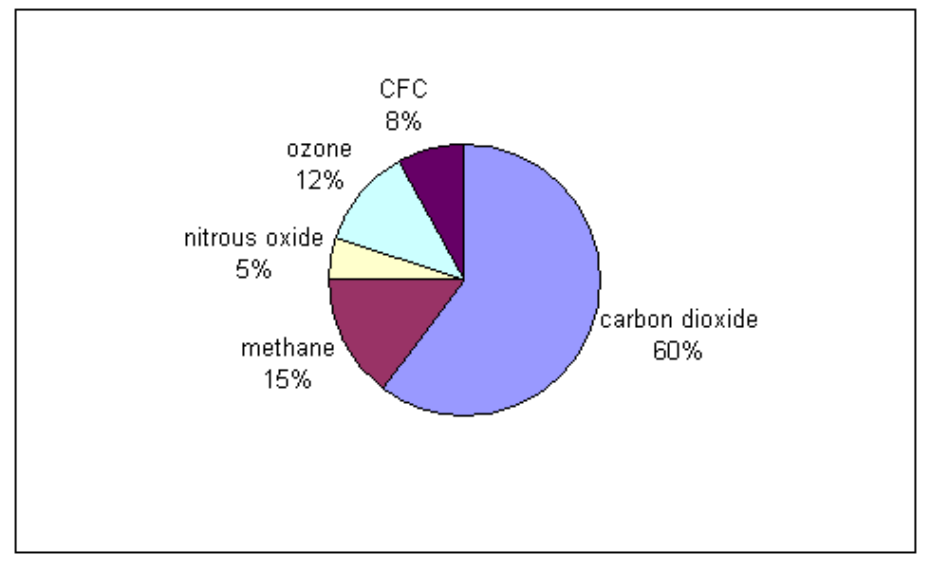

Fig: percentage of different greenhouse gases in greenhouse effect 


\section{Acid rain}

Carbon dioxide released from the fossil fuel, burning energy plants combine with moisture in the air and results in precipitation with high acid content. It has shown adverse impacts on forests, freshwater, soils, killing insects and aquatic life forms and also has impact on human health. Human problems include lung diseases like asthma and bronchitis. Acid rain also damage buildings, historic monuments and statues that contain large amounts of calcium carbonate. It also causes corrosion of metals.

- $\mathrm{H}_{2} \mathrm{O}+\mathrm{CO}_{2} \longrightarrow \mathrm{H}_{2} \mathrm{CO}_{3}\left(\mathrm{HCO}_{3}\right)^{-}+\mathrm{H}^{+}$ $\left[\mathrm{H}_{2} \mathrm{O}\right.$ - water, $\mathrm{CO}_{2}$ - carbon dioxide, $\mathrm{H}_{2} \mathrm{CO}_{3}$ - carbonic acid, $\mathrm{HCO}_{3}^{-}$- bicarbonate ion, $\mathrm{H}^{+}$hydrogen ion]

Acid rain is also caused by the ions released from sulphuric acid and nitric acid that makes rain water highly acidic.

- Formation of sulphuric acid:

$$
\mathrm{S}+\mathrm{O}_{2} \longrightarrow \mathrm{SO}_{2}+1 / 2 \mathrm{O}_{2}+\mathrm{H}_{2} \mathrm{O} \stackrel{\mathrm{SO}_{2}}{\longrightarrow} \mathrm{H}_{2} \mathrm{SO}_{4} \longrightarrow \mathrm{H}^{+}+\mathrm{SO}_{4}{ }^{--}
$$

[S - Sulphur, $\mathrm{O}_{2}$ - oxygen, $\mathrm{SO}_{2}$ - sulphur dioxide, $\mathrm{H}_{2} \mathrm{SO}_{4}$ - sulphuric acid, $\mathrm{SO} 4^{--}$- sulphate ion]

- Formation of nitric acid:

$$
\begin{array}{ll}
\mathrm{NO}+\mathrm{O}_{3} \longrightarrow & \mathrm{NO}_{2}+\mathrm{O}_{2} \\
\mathrm{NO}_{2}+\mathrm{O}_{3} \longrightarrow & \mathrm{NO}_{3}+\mathrm{O}_{2} \\
\mathrm{NO}_{3}+\mathrm{NO}_{2} \longrightarrow & \mathrm{N}_{2} \mathrm{O}_{5} \\
\mathrm{~N}_{2} \mathrm{O}_{5}+\mathrm{H}_{2} \mathrm{O} \longrightarrow & 2 \mathrm{HNO}_{3} \longrightarrow \mathrm{H}^{+}+\mathrm{NO}_{3}^{-}
\end{array}
$$

[NO - nitric oxide, $\mathrm{O}_{3}$ - ozone, $\mathrm{NO}_{2}$ - nitrogen dioxide, $\mathrm{NO}_{3}$ - nitrogen trioxide, $\mathrm{N}_{2} \mathrm{O}_{5}$ dinitrogen pentoxide, $\mathrm{HNO}_{3}$ - nitric acid, $\mathrm{NO}_{3}{ }^{-}$- nitrate ion]

\section{Global warming}

Carbon dioxide is a greenhouse gas i.e. heat trapping gas. So, it causes the earth's temperature to rise since its level is in increasing order. It has effects on oceans, ice and weather that include shrinking and thinning of ice making it vulnerable to atmospheric anomalies. The long term effect includes further ice melt, ocean warming, sea level rise and ocean acidification. High atmospheric carbon dioxide reduces ecosystem productivity and has direct impact on terrestrial life, crop production will be reduced and may lead to undernutrition.

\section{Ocean acidification}

Global warming also contributes to the phenomenon of ocean acidification. Ocean acidification is the process of ocean water absorbing more carbon dioxide from the atmosphere. Higher the level of carbon dioxide in atmosphere, higher will be acidification. 
Thus, fewer organismss can survive in warmer and less salty waters. Ocean acidification also refers as $\mathrm{pH}<7$ of ocean water ( $\mathrm{pH}$ is a scale indicating to acidity and alkalinity of aqueous solution, defined as the negative logarithm of hydrogen ion activity). Ocean acidification will affect the physiology of water breathing animals by increasing acidity in the tissues and body fluids. This can cause long term effects on metabolic functions, growth and reproduction.

\section{B. Carbon monoxide}

Carbon monoxide is a colorless, odorless, tasteless and toxic air pollutant that can be harmful when inhaled in large amounts. Its sources are cars, trucks and other vehicles or machinery that burn fossil fuels. A variety of items in home as unvented kerosene and gas space heaters, leaking chimneys and gas stoves also release carbon monoxide.

\section{Affects of carbon monoxide in pollution}

Carbon monoxide does not have impact on environment. Although it is a greenhouse gas, it contributes indirectly to climate change. Its presence affects concentration of other greenhouse gases like methane, ozone and carbon dioxide, creating particles and other harmful pollutants. Exposure of human to excessive of carbon monoxide may cause health problems like headache, dizziness, vomiting and nausea and also prolonged exposure has risk of heart disease.

Preventive care is very necessary when using battery backup detector, heating system, refrigerator, and placement of such goods should be ventilated, never burn charcoal indoor, etc. and all these equipment should be checked regularly by technicians to minimize the carbon monoxide related hazards.

\section{Chlorofluorocarbons}

Chlorofluorocarbons (CFCs) are nontoxic, noninflammable chemicals. Its sources are refrigerators, air conditioners, aerosol sprays, fire extinguishers, asthma inhalers, air crafts. Chlorofluorocarbons are partly or completely halogenated saturated hydrocarbons. Its constituents are carbon $(\mathrm{C})$, hydrogen $(\mathrm{H})$, chlorine $(\mathrm{Cl})$ and fluorine $(\mathrm{F})$, generated through volatile derivative of methane, ethane and propane. They are also commonly known by the DuPont brand name Freon.

\section{Affects of chlorofluorocarbon in pollution}

\section{1) Ozone layer depletion}

Ozone layer in the atmosphere protects us from harmful UV radiation coming from the sun. Ozone depletion means thinning of ozone layer present in upper atmosphere. Its main causes are chlorofluorocarbons. The ozone layer prevents the harmful wavelength of ultraviolet rays from passing through earth's atmosphere. They cause skin cancer, sunburn, permanent blindness and cataracts. In addition, increased surface UV radiation leads to 
increased tropospheric ozone which is a health risk to human. The most common forms of skin cancer include basal and squamous cell carcinoma, malignant melanoma. Increased UV radiation affects crops, has tendency to damage plant DNA and also affects the terrestrial ecosystem.

When CFCs comes in contact with sun's UV ray, then the chlorine atoms becomes loose. These chlorine atoms remain free in atmosphere until they meet up with ozone molecules. The chlorine atom and one of the oxygen atoms of ozone combine, leaving behind diatomic oxygen. When a free oxygen atom contacts this chlorine-oxygen compound, the two oxygen atoms combine to form molecular oxygen and chlorine goes off to devastate more ozone molecules (one chloride ion can react with one lakh ozone molecules in repeated cycles). Then molecular oxygen, unlike ozone molecules, cannot keep UV rays from reaching the earth's surface.

$$
\begin{aligned}
& \mathrm{O}_{2}(\mathrm{~g}) \underset{\mathrm{uv}}{ } \longrightarrow \mathrm{O}(\mathrm{g})+\mathrm{O}(\mathrm{g}) \\
& \mathrm{O}_{2}(\mathrm{~g})+\mathrm{O}(\mathrm{g}) \longrightarrow{ }^{\mathrm{Uv}_{3}}(\mathrm{~g}) \\
& \mathrm{CF}_{2} \mathrm{Cl}_{2}(\mathrm{~g}) \longrightarrow \mathrm{Cv}^{\mathrm{Cl}^{\bullet}+\mathrm{C}^{\bullet} \mathrm{F}_{2} \mathrm{Cl}(\mathrm{g})} \\
& \mathrm{Cl}^{\bullet}(\mathrm{g})+\mathrm{O}_{3}(\mathrm{~g}) \longrightarrow \mathrm{ClO}^{\bullet}(\mathrm{g})+\mathrm{O}_{2}(\mathrm{~g}) \\
& \mathrm{ClO}^{\bullet}(\mathrm{g})+\mathrm{O}(\mathrm{g}) \longrightarrow \mathrm{Cl}^{\bullet}(\mathrm{g})+\mathrm{O}_{2}(\mathrm{~g})
\end{aligned}
$$

[O $\mathrm{O}_{2}$ - oxygen, $\mathrm{O}_{3}$ - ozone, $\mathrm{CF}_{2} \mathrm{Cl}_{2}$-difluorodichloromethane, $\mathrm{Cl}^{\bullet}$ - chloride ion, $\mathrm{ClO}^{\bullet}$ hypochlorite]

\section{2) Climate change}

Climate change is the natural process but with increasing the different gases released from various sources causes the unnatural changes from shifting weather pattern that threaten food production, to rising sea level (flooding). The impacts of climate change are global. When destroying the ozone layer, CFCs also act to trap heat in the lower atmosphere, causing the earth to warm and change the weather. CFCs are subset of large group of climate changing gases called greenhouse gases. Without the drastic action to minimize the causes that cause climate change, these impacts in the future will be more difficult to handle and will be costly.

\section{Hydrocarbons}

Hydrocarbons are the chemical compound that is composed of hydrogen and carbon. Hydrocarbons are highly combustible, producing carbon dioxide, water and heat when burnt. Hydrocarbons are found naturally as petroleum, fuel, natural gas and lubricants. Greenhouse gases released during the combustion of hydrocarbons contributes to climate change. Some examples of hydrocarbon are methane, ethylene, acetylene, terpenes. The incomplete combustion of the hydrocarbon fuels also results in carbon monoxide pollution. Carbon dioxide is always released when hydrocarbons are burned. Combustion of oil causes the release of nitrogen oxide and sulphur dioxide. These oxides combine with water and 
oxygen in the atmosphere, creating nitric and sulphuric acid, which returns to earth's surface as acid decomposition or acid rain. Nitrogen oxides along with hydrocarbon pollutants, contributes to the formation of tropospheric ozone i.e. smog.

\section{Example}

Complete combustion:

$\mathrm{C}_{3} \mathrm{H}_{6}+\mathrm{O}_{2} \longrightarrow \mathrm{CO}_{2}+\mathrm{H}_{2} \mathrm{O}$

Incomplete combustion:

$\mathrm{C}_{3} \mathrm{H}_{6}+\mathrm{O}_{2} \longrightarrow \mathrm{C}+\mathrm{CO}+\mathrm{CO}_{2}+\mathrm{H}_{2} \mathrm{O}$

(Propane)

In above reaction, first step shows the complete combustion of propane and oxygen producing carbon dioxide and water, but in second step, hydrocarbon (propane) undergoes incomplete combustion with oxygen to produce carbon dioxide and carbon monoxide which are polluting agents, along water and carbon.

\section{E. Carbon disulphide}

Carbon disulphide is a colorless, volatile and inflammable liquid with sweet aromatic color. It is insoluble in water and much dense than water. It is used in manufacturing of perfumes, cellophane, rayon, floatation agents and as a solvent.

\section{Sources}

Carbon disulphide is a natural product of anaerobic biodegradation and is released to the atmosphere from oceans and landmasses as well as geothermal sources. It is used in large quantities as an industrial chemical for the production of viscose rayon fibres. In this technological process, for every kilogram of viscose produced, about 20-30 gm of carbon disulphide and 4-6 gm of hydrogen sulphide are emitted. Very small amount of carbon disulphide occurs in coal tar and in crude petroleum.

\section{Routes of exposure}

The main source of environmental pollution by carbon disulphide is emission into the air from viscose plants. Inhalation is the main route of carbon disulphide absorption in both occupational and environmental exposure. Carbon disulphide can contaminate juice and wine distilled from grapes harvested in vineyards treated with carbon disulphide. Dermal absorption of carbon disulphide can represent an additional route of entry in occupational exposure.

\section{Harmful effects of carbon disulphide}

Acute and subacute poisoning appear due to exposure to carbon disulphide and are characterized by predominantly neurological and psychiatric symptoms. In chronic exposure to carbon disulphide, the effects are seen on blood vessels in various organs and tissues, especially cerebral and renal arteries, producing encephalopathy and nephropathy. Its exposure also causes the risk of coronary heart disease (CHD). 


\section{F. Cyanide}

Cyanide is a toxic chemical compounds that consists of a carbon atom triple bonded to a nitrogen atom and the cyanide group is present as the anion $\mathrm{CN}^{-}$.

\section{Sources}

Cyanide is produced naturally by bacteria, algae, fungi and numerous species of plant like lima beans, cassava, almonds, seeds and pits of apples, cherry, pear, apricot and peach.

\section{Affects of cyanide in environment}

Cyanide forms ionic complexes of varyingstability with many metals which are less toxic than cyanide but weak acid dissociates complexes such as those of copper and zinc and will release cyanide back to the environment. Iron cyanide causes photochemical decomposition and will release cyanide if exposed to ultra violet light. In air, cyanide is present as gaseous hydrogen cyanide. A small amount of cyanide in air is present as fine dust particles. This dust eventually settles over land and water. Rain and snow help remove cyanide particles from air whereas gaseous hydrogen cyanide is not easily removed from the air by rain or snow. Most cyanide in surface water will form hydrogen cyanide and evaporate. However, the amount of hydrogen cyanide formed is generally not enough to be harmful to humans.

\section{Effects of cyanide in humans}

Exposure to cyanide can be deadly regardless of the amount and route of exposure. Severity of harmful effects depends on the form of cyanide, such as hydrogen cyanide gas or cyanide salts. Exposure to high concentration of cyanide for short time period harms the heart and the brain and may even cause coma and death. Some of the first indications of cyanide poisoning are rapid, deep breathing and shortness of breath, followed by convulsion and loss of consciousness which occurs rapidly. Skin contact with hydrogen cyanide or cyanide salts can irritate and produce sores.

\section{Harmful effects of carbon pollution in human beings}

- Chronic inhalation exposure to carbon black may result in temporary or permanent damage to lungs and heart.

- Carbon monoxide is both more readily absorbed and more firmly bound to hemoglobin of blood than oxygen and thus, even in small concentration, it is dangerous asphyxiant.

- Carbon tetrachloride and other chlorinated hydrocarbons damage the nervous system.

- High level of carbon dioxide can displace oxygen and nitrogen causing health problems. 
- Exposure to carbon dioxide can produce a variety of health effects like headache, dizziness, restlessness, difficulty in breathing, sweating, tiredness, increased heart rate, elevated blood pressure, coma asphyxia and convulsions.

- $\quad$ Prolonged exposure to carbon dioxide may change the level of bone calcium and body metabolism.

- $\quad$ Exposure from breathing high carbon monoxide levels can cause miscarriage, damage to developing fetus, seizures, coma and heart failure.

- Dermal interaction with chlorofluorocarbon may cause skin irritation or dermatitis.

- Inhalation of chlorofluorocarbon affects central nervous system including lightheadedness, headache tremors, convulsions and that disturb heart rhythm.

\section{Minimization of carbon pollution}

\section{- $\quad$ Reducing fossil fuel dependence}

Burning coal to produce energy creates carbon dioxide emulsion and contributes to irreversible climate change. Fossil fuels should be switched with sustainable energy sources such as wind or solar power can help to reduce carbon dioxide emission.

- Measuring carbon footprint

A carbon footprint can be measured by undertaking a greenhouse gas emissions assessment. Once the size of carbon footprint is known, strategy to reduce it through technological developments can be made with better process and product management.

\section{- $\quad$ Carbon capping}

Carbon cap is a term for government regulatory program designed to limit the total level of emissions of certain carbon compound, particularly carbon dioxide, as a result of industrial activity. The cap on greenhouse gases emission that drives global warming is a firm limit on pollution. The cap gets stricter over time and also limits harmful emissions.

\section{- $\quad$ Reuse and recycle}

Greenhouse gas emissions result from extraction of resources, manufacturing, transport and final disposal of consumer products and packaging, building components and passenger vehicles, but excluding food. By recycling item which is longer used, carbon emissions can be reduced from the provision of goods.

Carbon dioxide from the atmosphere converts into carbon neutral fuel, suggesting such technology could be meaningful part of the fight against climate change. Recycle is one of the major factors to reduce the greenhouse gases emission by recycling energy consumption. In factories, carbon dioxide is treated with alkaline liquid within the factory tower where acid and based are separated. Hence, frozen liquid with 
carbon dioxide reached into a slury that is combined with hydrogen to make liquid fuels like gasoline and jet fuel.

\section{- Bioenergy with carbon capture and storage}

It is another way to use photosynthesis to combat climate change. It is the process of using biomass for energy in the industrial, power or transportation sectors and capturing the embodied carbon before it is released back to the atmosphere and then storing it either underground or in long lived products like concrete. Energy is extracted in useful forms (heat, electricity, biofuels, etc.) as the biomass is utilized through combustion, fermentation or pyrolysis.

\section{References}

Finar, I.L. organic chemistry vol. 2, Dorling Kindersley (India) Pvt. Ltd. 2012.

Morrison and Boyd organic chemistry, by arrangement with Allyn Bacon Inc. $4^{\text {th }}$ edition. Sharma P.D., Ecology and Environment, Rastogi publication, Gangotri Shivaji road Meerut. Odum, Eugene, Fundamentals of Ecology, P. Nataraj publication, Dehradhun, $3^{\text {rd }}$ edition.

U.S. Environmental Protection Agency. Integrated Risk Information System (IRIS) on Carbon disulphide. National center for Environmental Assessment, Office of Research and Development, Washington, DC, 1999.

The Merck Index. An Encyclopedia of Chemicals, Drugs and Biologicals. $11^{\text {th }}$ edition. Ed. S. Budavari. Merck and Co. Inc., Rahway, NJ. 1989.

Carbon disulphide. Geneva, World Health Organization, 1979 (Environmental Health Criteria, No. 10)

Beauchamp, R.O., Jr. et al. a critical review of the literature on carbon disulphide toxicity. CRC critical review in toxicology, 1983.

Vigliani, E.C. chronic carbon disulphide poisoning, a report on 100 cases. Medicina del lavoro, 1946. 